\title{
VERMICOMPOSTING FROM BAGASSE BY USING EUDILUS
}

\section{EUGENIEA}

\author{
B.A.Bhandarkar ${ }^{1}$, S.A.Kakde ${ }^{2}$, S.K.Sonar ${ }^{3}$, A.S.Sayyed ${ }^{4}$ \\ ${ }^{1}$ Asst.Professor, Civil Engg Dept, G.H.R.I.E.M Jalgaon, MH, India \\ ${ }^{2}$ Lecturer, Civil Engg Dept, G.H.R.I.E.M Jalgaon, MH, India \\ ${ }^{3}$ Lecturer, Civil Engg Dept, G.H.R.I.E.M Jalgaon, MH, India \\ ${ }^{4}$ Lecturer, Civil Engg Dept, G.H.R.I.E.M Jalgaon, MH, India
}

\begin{abstract}
Enhancement of environmental quality is an accepted national goal. Few decades back when population was less. Energy was inexpensive and raw materials were abundant and, hence recycling of the used materials was not required but with the advent of industrialization and urbanization the problem of waste disposal increased. High population density. Intensive land use for residential, commercial and industrial activities led to adverse impact on the environment, Excessive use of sugar cane in our day life has converted the Bagasse on our day to day life has solid waste. Considering waste as a major component of organic solid waste In cities like Jalgaon, Maharashtra which is having its large quantity of Sugarcane Production to importance in Indian tradition, the generation of Sugarcane Waste is in abundance. According to current survey, the Jalgaon, city of M.H. in India with a population of about 4.5 lakhs produces about 6225 tons of Sugarcane waste including 3000 tones Bagasse waste per annum 5. Organic could be utilized by making reuse for four ' $F$ ' i.e. Fertilizer, Fodder, Fooder, Food and Fuel. The organic flower waste should be disposed of properly to avoid fly nuisance, foul smells and development of unhygienic conditions. Vermicomposting is one of the process like which we can achieve this goal. Eudrilus Eugenia, Eisenia Fetida and Perionyx excavates species of earthworms have been used in this process. The conventional composting methods, though effective and provide revenue in return takes long time. Hence, more release of energy means more bacterial biomass, which in-turn speed-up waste decomposition to an higher rate than that possible under anaerobic conditions
\end{abstract}

Keywords: Rate of Vermicomposting, Bagasse Waste, Eudilus Eugenie species of earthworm to treat the waste,

\section{TYPES OF WASTE}

Waste biomass from domestic, agricultures, urban and industrial sources is the main cause of organic pollution in developing countries like India. A major percentage of refuse (more than $60 \%$ ) constitute decomposable materials. Solid waste are all the wastes arising from human and animal activities that are normally solid and that are discarded as useless or unwanted. From an economist's point of view "wastes are those which are cheaper to be thrown out than making use of them" Vermicomposting from sugarcane waste (bagasse) provides one of the best examples of renewable based cogeneration yet it remains largely unexploited. Until now, the potential for bagasse generation of Vermicomposting has been largely unquantified. This report was compiled to highlight the advantages and main issues of bagasse generation and the potential it offers for Vermicomposting production.

Solid waste management is one of the most challenging issues in urban cities, which are facing a serious pollution problem due to the generation of huge quantities of solid waste. This paper presents an assessment of the existing situation of municipal solid waste management (MSWM) in major cities in India. The quantity and composition of MSW vary from place to place, and bear a rather consistent correlation with the average standard of living. Extensive field investigations were carried out for quantification, analysis of physical composition, and characterization of MSW in each of the identified cities

E.g. 1: Municipal Solid Waste

E.g. 2: Industrial Solid Waste

E.g. 2: Agricultural Solid Waste

\subsection{Quantityof Solid waste}

The quantity of municipal solid waste generated depends upon the factors such as population, food habits standard of living and degree of commercial and industrial activities. In addition to this it also depends upon the degree of residential areas, institutions and business establishments which recycles their wastes. As per NEERI, per capita contribution of M.S.W. for different Indian cities varies between 0.15 to $0.35 \mathrm{~kg}$ per day per capita in metropolitan cities like Mumbai and Calcutta. In other developing countries this value varies between 0.25 to $0.87 \mathrm{~kg}$ per capita per day.

\subsection{Composting}

To maintain the hygienic conditions, the municipal solid waste has to be removed and cleared off from its generation point, the disposal of MSW includes collection, transportation and its removal and dumping for the processing the disposal of MSW may be with treatment or without treatment. Methods of disposal of MSW in relevance to developing countries are given below. If the 
organic materials, excluding plastics, rubber and leather are separated from municipal solid wastes and are subjected to bacterial decomposition, end product remaining after dissimulators and assimilatory bacterial activity is called compost, or humans. The entire process involving both the desperation and bacterial conversion of the organic solid wastes is known as composting. Decomposition of the organic solid waste may be accomplished either aerobically or an aerobically, depending on the availability of oxygen

\subsubsection{Principle of Composting}

Paragraph comes content here. Paragraph comes content here. Paragraph comes content here. Paragraph comes content here. Paragraph comes content here. Paragraph comes content here. Paragraph comes content here. Paragraph comes content here. Paragraph comes content here. Paragraph comes content here. Paragraph comes content here. Paragraph comes content here. Paragraph comes content here. Paragraph comes content here.

$$
\begin{array}{cc}
4 a+b-2 c-3 d & b-3 d \\
\mathrm{C}_{\mathrm{a}} \mathrm{H}_{\mathrm{b}} \mathrm{O}_{\mathrm{C}} \mathrm{N}_{\mathrm{a}}+-------+\mathrm{O}_{2}---->\mathrm{a} \mathrm{CO}_{2}+\underset{4}{2}+--\mathrm{H}_{2} \mathrm{O}+\mathrm{dNH}_{\mathrm{c}}
\end{array}
$$

\subsection{Sugarcane Production by Country}

India has just over 500 sugar mills, 45 with nine states (Uttar Pradesh, Bihar, Punjab and Haryana in the northern region; Maharashtra \& Gujarat in the western region and Andhra Pradesh, Tamil Nadu and Karnataka in the southern region, holding $95 \%$ of them. Most mills are either privately owned or co-operatives.46 Figure 9 gives details of the distribution of sugar mills in India. In India, the crushing season lasts 100-250 days per annum depending on the region weather, irrigation and cultivation practices as well as cane availability, in itself a function of the prices paid to cane growers. Sugar mills have capacities ranging from below 1,250 TCD to 10,000 TCD. The Indian Government has now established minimum capacity criteria for new sugar mills standing at 2,500 TCD

Government has now established minimum capacity criteria for new sugar mills standing at 2,500 TCD

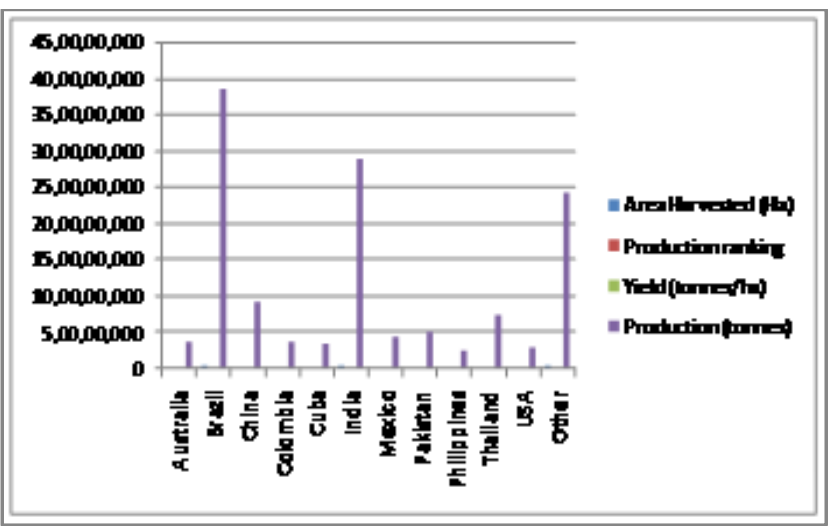

Graph: Sugarcane Production Country

\section{BIOTECHNOLOGY}

Biotechnology is the use of living organisms or of substances obtained from living organisms to make products of value from the integrated use of life science, chemical science and engineering science. The term biotechnology was coined during the late 1970's. Biotechnology can be broadly classified as microbial. Biotechnology can be broadly classified as microbial. Biotechnology, plant biotechnological agent involved. Biotechnology has immense potential for use in agriculture forestry, food industry pollution control and environment.

\subsection{Earthworm Biotechnology}

It is a aspect of biotechnology involving the use of earthworms as versatile natural bioreactors for effective treatment and recycling of organic solid and liquid wastes. Earthworm plays a key role in the treatment and stabilization of organic wastes. This technology is a environment friendly method of spoiled waste stabilization. Earthworms are invertebrates which is a important group of phylum annelid (Segmented worms) found in moist terrestrial environment. The phylum annelid is divided into four different classes and the earthworms belong to class chatpoda (i.e. having bristle like appendages) and order Oligochaeta (i.e. having few bristles). Their characteristic features are that they are externally segmented with a corresponding internal segmentation, and usually have setae on all segment attached, Fig. 2.1 shows some of the details of earthworms body structure. They produce cocoons containing eggs. Which hatch in to immature worms? Earthworms range in size from a fraction of $\mathrm{cm}$ to exceptional individuals of Megascolides australis which may measure $2.75 \mathrm{~m}$ in length and $3 \mathrm{~cm}$ in diameter. There are about 1800 species of earthworms distributed all over the world. The names of families which are terrestrial are given below. The life cycle of three earthworm species which are widely used in Vermicomposting is given below.

(1) Eisenia Foetida

(2) Eudrilus Eugeniae

(3) Perionyx Excavatus

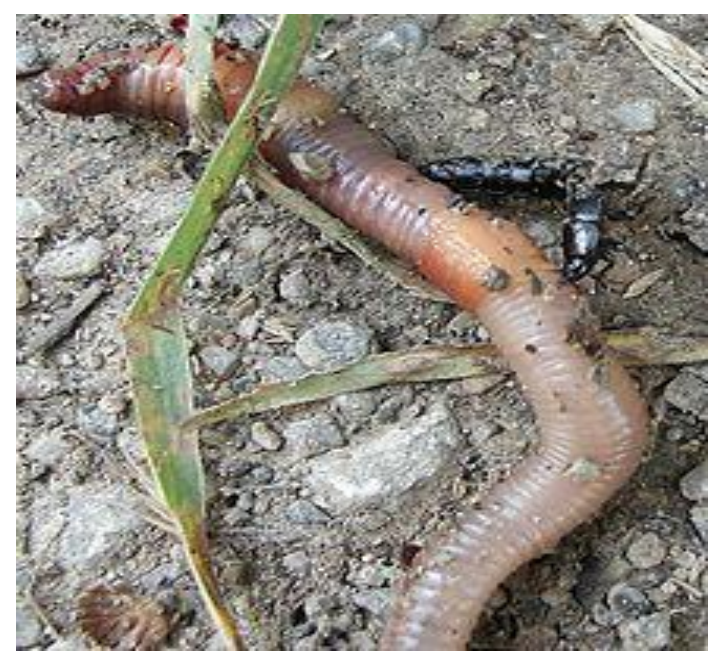

Fig 1: Eudrilus Eugeniae 


\subsection{Earthworm Biology}

Earthworms are usually red or pink, long cylindrical and divided into rings or segments. Adult's earthworms have a swollen band (clitella) near the front end. It covers about 5 to 10 segments, and is a part of the reproductive system. The color of earthworms is mainly due to the hemoglobin in the worm's blood. Earthworms have no special breaking organs. Oxygen is absorbed and waste gases are eliminated by diffusion through the skin surface. The respiratory gasses must be dissolved in water to be transferred. Gland cells in the skin secrete mucus to keep the surface moist and lubricate the body as it moves in the soil. This is why earthworms are moist and slippery to the touch, they constantly replace water lost by evaporation from the surface, they cannot live in very dry soils. he body structure of an earthworms is basically a rather simple arrangement of one tube inside another. The outer tube is the muscular body wall, and the inner tube is the digestive system, with a fluid filled space separating them. This space is divided into more or less water tight compartments by membranes called septa, which are slightly muscular. They correspond in position with the external grooves between segments.

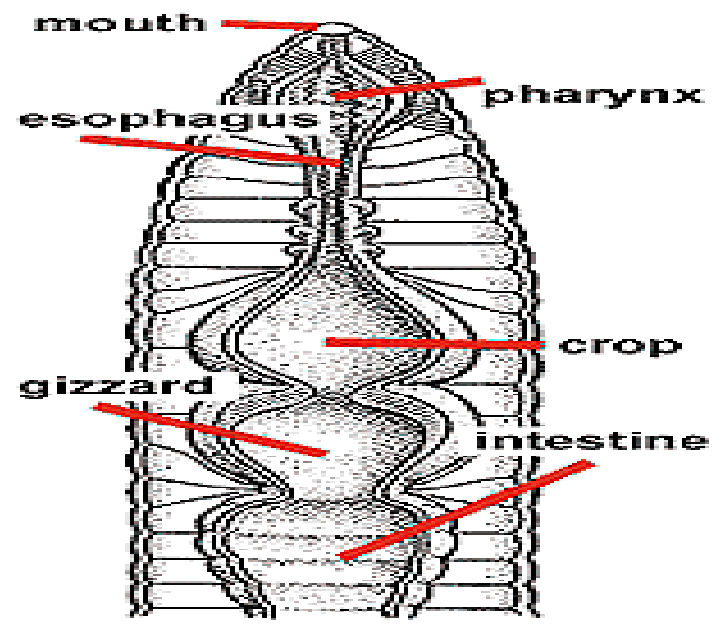

Fig 2: The Natural Tubular Bioreactor

\section{MATERIALS \& METHODS}

Present investigation were undertaken to further explore the conversion of organic solid waste into Vermicomposting with wide range of initial concentration of organic Sugarcane waste. Quantative analysis was carried out by collecting Bagasse waste sample and The chemical parameters were determined at the Soil, Water \& Fertilizer Testing Laboratory, Sambhaji Chouk, Untavadi, Nasik

\subsection{Qualitative \& Quantitative Analysis}

\subsubsection{Sources of Bagasse Waste}

In India Sugarcane play a major role in day to day life we use Bagasse at several occasions like:
I. To made sugar
II. To made Juice
III. To made paper industry

A detail survey of Bagasse and other Molasses produced at Jalgaon \& Dhule city is done for different weather form Sugarcane factory and Different Shops, Faizpur DistJalgaon \& Shahada Dist- Dhule and from Various Juice shopkeepers around the Jalgaon and Dhule (Table 4.1).

\subsubsection{Composite Sample:}

The composite sample was prepared by collecting $5 \mathrm{~kg}$ Bagasse waste from each Juice shopkeeper \& Farmers. Total mass of sample collected in a day was nearly 50kg. After mixing fully, $20 \mathrm{~kg}$ of this composite was transferred to another container.

\subsubsection{Parameters Selected for Solid Waste Analysis}

$$
\begin{array}{cl}
\text { I. } & \text { Organic matter, COD, TOC } \\
\text { II. } & \text { Total Nitrogen }
\end{array}
$$

\subsubsection{Analytical Methods:}

Sample were collected and analyzed as per standard procedure described in standard Methods.

\subsubsection{Instruments Used:}

- $\quad$ Digital pH Meter (pp - 9046 Philips)

- $\quad$ Spectrophotometer spectronic-21)

- Infrared Moisture Balance (optics Technology)

- $\quad$ Systronics Flame Photometer 'Mediflame' 127

- Cooling Incubator

- Muffle Furnace

- COD Analyzer

\subsubsection{Sample Preparation for Analysis:}

i) Organic Matter: Sample is oven dried and crushed to fine powder then standard Method 209-D followed.

ii) COD: Sample is oven dried and crushed to fine powder then standard method 508-B followed.

iii) Total Nitrogen: Sample is oven dried and crushed to fine powder then standard method 320-B followed.

iv) $\mathrm{Ca}, \mathrm{Mg}, \mathrm{Na}, \boldsymbol{\&} \mathbf{k}^{\mathbf{8}}$ : Oven dried sample passed through 75 micron sieve is mixed with ammonium acetate solution. Stir the suspension and keep overnight and filter the supernatant then standard method 311-C, 325-B \& 322-B followed for $\mathrm{Ca}, \mathrm{Mg}, \mathrm{Na}$ and $\mathrm{K}$ respectively.

v) $\mathbf{p H}$ : Sample is air - dried and crushed to fine powder. $10 \mathrm{gm}$ sample is mixed with $20 \mathrm{ml}$ distilled water and stir immediately with glass rod for half an hour then Standard method 423 followed.

\section{vi) Total Organic Carbon ${ }^{6}$}

\section{METHODOLOGY}

The vermiculture ecosystem involves harnessing the activities of beneficial soil bacterial and process flower waste by suitably combining flower waste with necessary additives. Here soil bacteria serve as the processing work force, earthworms regulate the bacterial activity and process rock particles to supply inorganic nutrients. This methodology can be used for quantitative design and 
monitoring criteria for (a) organic processing, (b) health care for soil and (c) health care for water bodies.

\subsection{Reactor Set - Up}

Bagasse waste was mixed in different proportions to study the conversion rate and growth of worms. The population increase/decrease were recorded in the given time interval. The Six treatment combinations of Bagasse waste and block cotton soil were prepared by weight on dry basis.

BAB -1.Worm: Soil: Bagasse : : 1 : $05: 05$

BAB -2. Worm: Soil: Bagasse : : 1 : $05: 10$

BAB -3 Worm: Soil: Bagasse : : $1: 10: 10$

BAB -4. Worm: Soil: Bagasse : : $1 \quad 10: 15$

BAB -5 Worm: Soil: 1 : 05

BAB -6 Worm: Soil: $1: 10$

\subsection{Procedure}

A definite quantity of Eudilus Eugeniae earthworms was introduced into reactor, ten days after the preparation of feed mix. The containers were now left undisturbed. Most of the material was heaped up along with worms on the ground. The worms having the tendency of downward movement moved from the top of the heap to the bottom and formed a cluster. These worms were harvested and live weight in each reactor was recorded.

The Vermicomposting was dried in shade for one day and passed through 3 to $4 \mathrm{~mm}$ size sieve to recover the small worms and cocoons (egg cases). The observed changes in biomass and increase in population were recorded separately. The compost was separated by sieving to remove the unconverted materials and weight to get the percent recovery of compost from treatment. The organic matter and micro nutrients were assayed in the used organic mix before and after the conversion as per standard Methods ${ }^{7}$.

Reactor BAB-1, BAB-2, BAB-3, BAB-4 have earthworm along with soil-flower mix while reactor BAB-5 \& BAB-6 have earthworms along with soil only. Parameters in composted Bagasse are obtained by subtracting parameter in composed soil from parameter in composed soil-flower mix. Thus parameter in reactor $\mathrm{BAB}-1 / \mathrm{BAB}-2$ minus in reactor $\mathrm{BAB}-5$ and in reactor $\mathrm{BAB}-3$ / $\mathrm{BAB} 4$ minus in reactor $\mathrm{BAB}-6$ will give parameter in composted flower in reactor BAB-1, BAB-2, BAB-3, \& BAB-4 respectively.

Table 1 Compost Ingredients

\begin{tabular}{|c|c|c|c|c|c|c|c|c|}
\hline \multirow{3}{*}{ Reactor } & \multirow{3}{*}{$\begin{array}{l}\text { Wt of } \\
\text { Earthworm } \\
\mathrm{s} \\
\text { gm }\end{array}$} & \multirow{2}{*}{ Wt of Soil } & \multirow{2}{*}{$\begin{array}{l}\text { Wt of } \\
\text { Bagasse }\end{array}$} & \multirow{3}{*}{$\begin{array}{l}\text { WE: WS } \\
\text { :WB }\end{array}$} & \multicolumn{2}{|c|}{$\begin{array}{l}\text { Weight of } \\
\text { Earthworm }\end{array}$} & \multicolumn{2}{|c|}{ Weight of Vermicomposting } \\
\hline & & & & & Initial & Final & Initial & Final \\
\hline & & $\mathrm{gm}$ & $\mathrm{Gm}$ & & $\mathrm{gm}$ & $\mathrm{gm}$ & $\mathrm{gm}$ & $\mathrm{gm}$ \\
\hline BAB-1 & 60.00 & 300.00 & 300.0 & $1: 05: 05$ & 60.00 & 127.08 & 600.00 & 312.00 \\
\hline BAB-2 & 50.00 & 250.00 & 500.0 & $1: 05: 10$ & 50.00 & 105.50 & 750.00 & 400.05 \\
\hline BAB-3 & 50.00 & 500.00 & 500.0 & $1: 10: 10$ & 50.00 & 105.30 & 1000.0 & 531.00 \\
\hline BAB-4 & 50.00 & 500.00 & 750.0 & $1: 10: 15$ & 50.00 & 104.50 & 1250.0 & 708.75 \\
\hline BAB-5 & 50.00 & 250.00 & 0.0 & 1:05:00 & 50.00 & 84.35 & 250.00 & 171.75 \\
\hline BAB-6 & 50.00 & 500.00 & 0.0 & $1: 10: 00$ & 50.00 & 83.55 & 500.00 & 335.50 \\
\hline
\end{tabular}

Table 2 Characteristics Bagasse Waste \& Soil Waste

\begin{tabular}{|c|c|c|c|c|c|}
\hline \multirow{5}{*}{$\begin{array}{l}\text { Sr. } \\
\text { No }\end{array}$} & \multirow{4}{*}{ Name of Parameter } & \multicolumn{4}{|c|}{ Initial Parameters ( Based on Dry Matter ) } \\
\hline & & \multicolumn{4}{|c|}{ Soil + Bagasse } \\
\hline & & \multicolumn{4}{|c|}{ REACTOR } \\
\hline & & BAB-1 & BAB-2 & BAB-3 & BAB-4 \\
\hline & $\begin{array}{l}\text { WE : WS :WB } \\
(\mathrm{WS}+\mathrm{WB}) \mathrm{gm}\end{array}$ & $\begin{array}{l}0: 5: 5 \\
600\end{array}$ & $\begin{array}{l}0: 5: 10 \\
750\end{array}$ & $\begin{array}{l}0: 10: 10 \\
1000\end{array}$ & $\begin{array}{l}0: 10: 15 \\
1250\end{array}$ \\
\hline 1 & Organic Matter & 338.280 & 516.900 & 563.800 & 798.800 \\
\hline 2 & COD & 180.000 & 287.500 & 315.000 & 440.000 \\
\hline 3 & Total Organic Carbon & 110.820 & 167.500 & 184.700 & 259.850 \\
\hline
\end{tabular}




\begin{tabular}{|l|l|l|l|l|l|}
\hline 4 & Total Nitrogen & 01.036 & 00.969 & 01.723 & 01.832 \\
\hline 5 & Calcium & 04.311 & 06.593 & 07.185 & 10.105 \\
\hline 6 & Magnesium & 00.903 & 01.003 & 01.505 & 01.755 \\
\hline 7 & Sodium & 15.300 & 15.500 & 25.500 & 28.250 \\
\hline 8 & Potassium & 04.590 & 07.225 & 07.650 & 11.050 \\
\hline 9 & C/N Ratio & 106.970 & 172.980 & 106.950 & 141.840 \\
\hline 10 & Ph & 6.9 & 6.6 & 6.9 & 6.72 \\
\hline
\end{tabular}

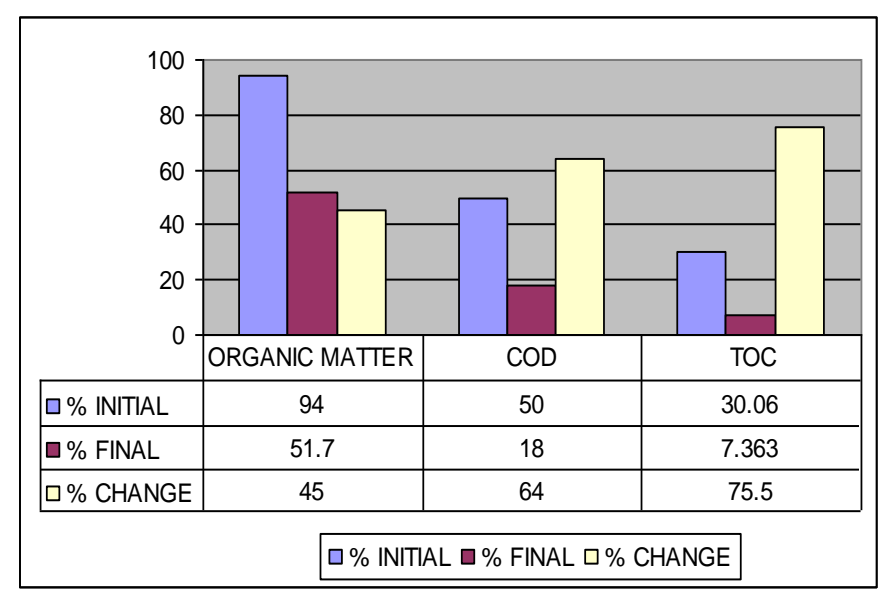

Graph 2 Bar Chart for Organic Matter, COD \& TOC

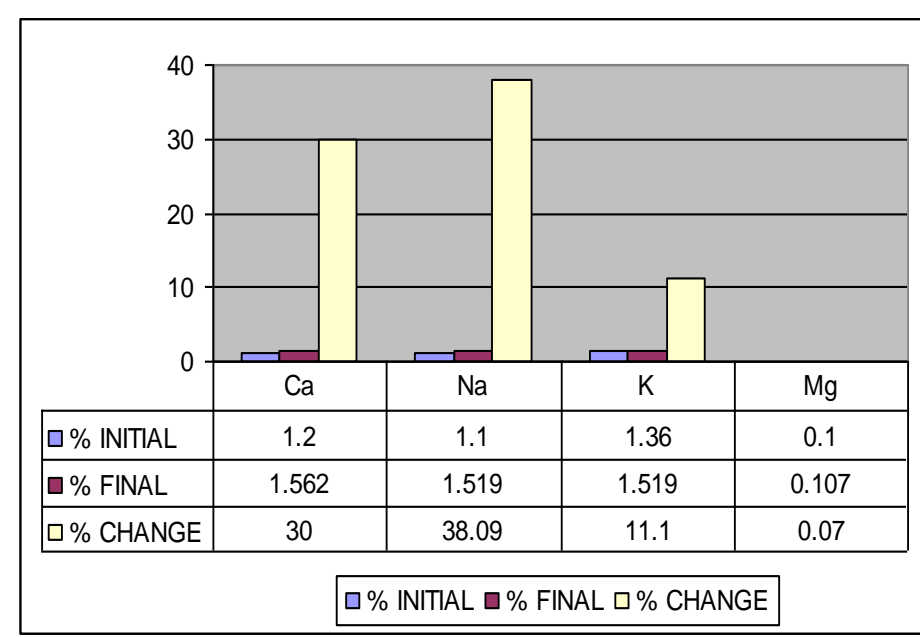

Graph 3 Bar Chart for $\mathrm{Ca}, \mathrm{Na}, \mathrm{K}, \& \mathrm{Mg}$

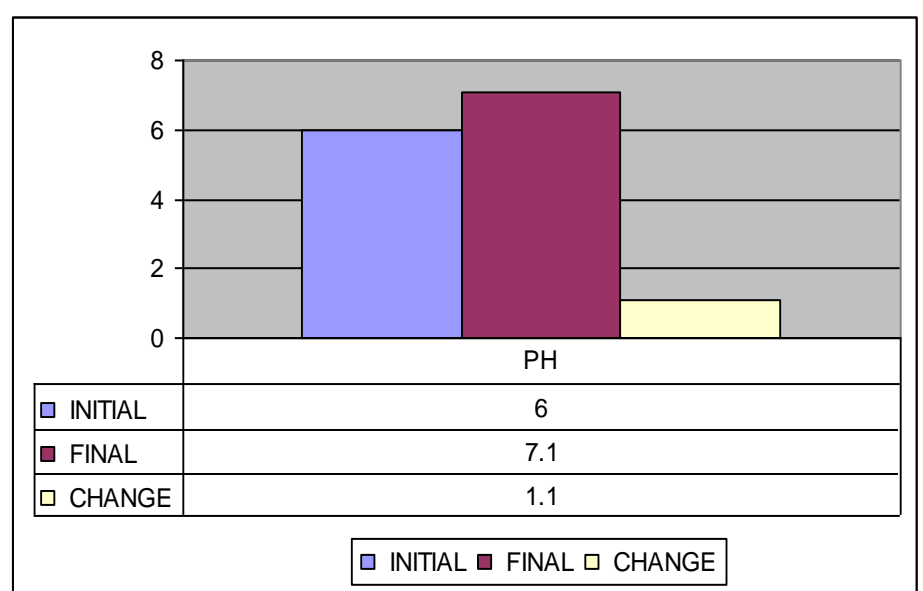

Graph 4 Bar Chart for $\mathrm{P}^{\mathrm{H}}$

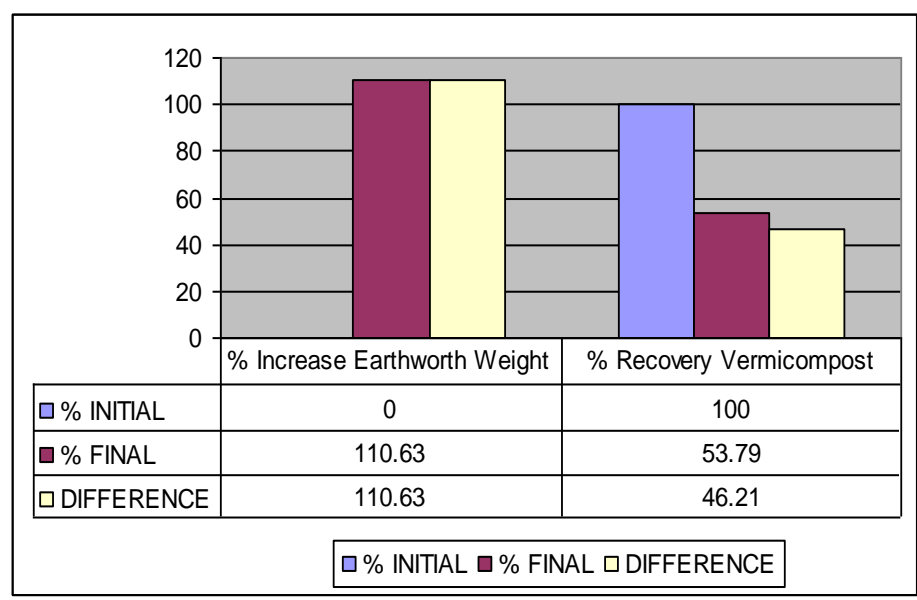

Graph 4: \% Increase Weight of Earthworm \& Recovery Vermicomposting

\section{RESULTS}

1) Earthworm species "Eudilus Eugenia" is capable to convert 50 percent organic matter of Bagasse waste into Vermicomposting (Table 407)

2) $\mathrm{COD}$ and TOC of Bagasse waste reduced by 64 percent and 75.5 percent respectively of its initial value in 45 Days period.

3) The initial acidic $\mathrm{pH}$ get buffered to neutral due to Vermicomposting.

4) $\mathrm{Ca}, \mathrm{Mg}, \mathrm{Na}$, and $\mathrm{k}$ are significantly increasing in Vermicomposting (Fig 4.10).

5) There is a fourfold increase in nitrogen content. 
6) $\mathrm{C} / \mathrm{N}$ ratio 715.71 drastically reduced to 54.44 in 45 Days period.

7) Bio-mass weight doubles up in 45 Days period.

8) Weight of Bagasse reduced to 53.79 percent of initial weight

\section{CONCLUSIONS}

1) Eudrilus Eugenie vermiculture ecosystem can process Bagasse solid containing the vermiculture ecosystem is a excellent biomedium for processing waste organics. Here earthworms farm bacteria and Sugarcane Waste, and the resulting in soil processes feed plants through need based nutrients.

2) Environmental engineering cum agricultural properties of Bagasse waste are substantially improved after Vermicomposting. Not only this, pollution causing parameters such as total organic matter, COD, and TOC are also reduced simultaneously soil fertilizing elements like $\mathrm{Ca}, \mathrm{Mg}, \mathrm{Na}$, and $\mathrm{k}$ also improved. $\mathrm{C} / \mathrm{N}$ ratio is reduced to 54.44 (nearing to 40), which is beneficial for fast decomposition.

3) Vermicomposting, a bionnoculant of beneficial soil bacteria and earthworm cocoons is a excellent additive for soil rejuvenation and bio sanitation. A feed of vermicasting will enable city gardeners to utilize waste organics, such extensive utilization of waste organics is the key to suitable agriculture, sanitation and wasted land development.

4) As a processing system, the Vermicomposting of organic waste is very simple. Worms ingest the waste material break it up in their rudimentary gizzards - consume the digestible putrefiable portion, and then excrete a stable, humus-like material that can be immediately marketed and has a variety of documented benefits to the consumer.

5)nVermitechnology can be a promising technique that has shown its potential in certain challenging areas like augmentation of food production, waste recycling, management of solid wastes like Sugarcane Waste, Flower waste etc

6) There is no doubt that in India, where on side pollution is increasing due to accumulation of organic wastes and on the other side there is shortage of organic manure, which could increase the fertility and productivity of the land and produce nutritive and safe food. So the scope for Vermicomposting is enormous.

\section{REFERENCES}

[1] Bhide, A.D. \& Sundarshan, B.B. "Solid Waste management in Developing Countries", Indian national Scientific Documentation Center, New Delhi-67, P.1, 14,15, 19-21, 81-88, 101, 135, 2004.

[2] Jakobsen, S., 1995. Aerobic decomposition of organic wastes 2. Value of compost as fertilizer Resource. Conserve. Recycle., 13: 57-71.

[3] World Energy Outlook 2010 and Renewable "Economic value of fossil-fuel consumption subsidies by country, 2009 “P.3

[4] Zhong Z.Y, and Q.X Zhou 1999. Sanitation landfill technology for refuge. Urban Environment and Urban. Ecology. China, 2: 17.
[5] S. C. Natu “ Bagasse Based Cogeneration, India Marching Ahead "Appendix - II Policy framework of various States as of March, 2005, India.

[6] N.C. Jalaja, D. Neelamathi, T.V. Sreenivasan "AsiaPacific Association of Agricultural Research Institutions (APAARI)" P. 6, 2008

[7] Bagasse Cogeneration-Global Review and Potential,Aurelie Morand,Research Executive, WADE aurelie.morand@localpower.org.,June- 2004

[8] Sunil Kumar , J.K. Bhattacharyya , A.N. Vaidya , Tapan Chakrabarti, Sukumar Devotta, A.B. Akolkar Assessment of the status of municipal solid waste management in metro cities, towns in India: An insight, (NEERI), Nehru Marg, Nagpur, 2008

[9] Mane T.T.1 and Hingane Hemalata N." Existing Situation of Solid Waste Management in Pune City, India P. 243, 2011

[10] Peavy, H.S., Rowe Jaiswal, P.L, “ Hand Book of manures and Fertilizers", Indian Agricultural Research Institute, New Delhi, books.google.co.in, P-67-87, 1982, 1999.

[11] Bhavlkar, Vidula and Bhawalkar, Uday, "Vermiculture Biotechnology". BERI, Pune, P.4-7, 12-16, 110-124, 213-220, 2000.

\section{BIOGRAPHIES}

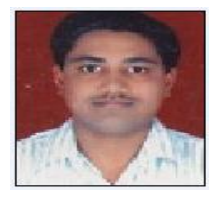

B.A.Bhandarkar worked as Asst.Prof. at G.H.RI.E.M

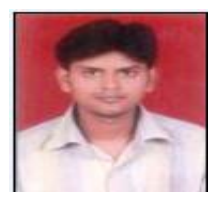

S.A.Kakade worked as Asst.Prof. at G.H.RI.E.M

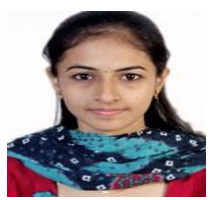

S.K.Sonar worked as Asst.Prof. at J.I.E.M.S

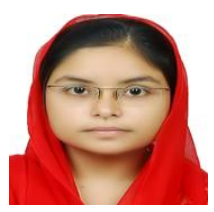

Aaisha.Sayyed worked as Asst.Prof. at G.H.RI.E.M 